\title{
FLIGHT SAFETY IN THE ASPECT OF BIRD STRIKES IN POLISH AIR FORCE
}

\section{BEZPIECZEŃSTWO LOTÓW W ASPEKCIE KOLIZJI STATKÓW POWIETRZNYCH Z PTAKAMI ZAISTNIALYCH W LOTNICTWIE SZ RP}

\author{
Janusz Ćwiklak, Henryk Jafernik \\ Wyższa Szkoła Oficerska Sił Powietrznych \\ e-mail: jcwiklak@wp.pl,henryjkj21@interia.pl
}

\begin{abstract}
The paper presents analysis of bird strikes, that occurred in Polish Air Force. Data of Polish Air Force were used to analysis. Mentioned analysis concern such problems as time of day, height, kind of flight operation, severity of bird strikes. It is considered, that the results of researches can be used to determine bird strikes hazard and elaborate SMS in the context of bird strikes for military air bases.
\end{abstract}

Keywords: flight safety, bird strikes

Streszczenie: Tematem publikacji jest analiza zdarzen lotniczych zwiąanych $z$ bezpieczeństwem lotów $w$ aspekcie kolizji statków powietrznych $z$ ptakami zaistniatych w lotnictwie Sit Zbrojnych RP. Przedmiotowa analize przeprowadzono na podstawie danych Sit Powietrznych RP. Ze względu na charakter opracowania ograniczono się do wyboru niektórych kryteriów analizy takich jak: pora roku, wysokość, etap lotu, rodzaj uszkodzeń zaistniałych podczas kolizji. Zakłada się, że wyniki badań moga być wykorzystane przy określaniu stopnia zagrożeń oraz w systemie zarzadzania bezpieczeństwem.

Stowa kluczowe: bezpieczeństwo lotów, kolizje statków powietrznych z ptakami 
Flight safety in the aspect of bird strikes in Polish Air Force.

Bezpieczeństwo lotów $w$ aspekcie kolizji statków powietrznych z ptakami...

\section{Wstęp}

Problem bezpieczeństwa lotów jest niezmiernie istotną kwestią funkcjonowania lotnictwa. Jak wskazują wnioski z przeprowadzonych analiz, jednym z czynników, który znacząco wpływa negatywnie na bezpieczeństwo lotów, jest potencjalna możliwość kolizji statków powietrznych z ptakami, szczególnie na lotnisku i w jego pobliżu $[2,9]$.

Z literatury związanej z przedmiotem badań wynika, że straty występujące w tego typu zdarzeniach osiągają wartość setek milionów dolarów rocznie (dane FAA), nie licząc ofiar ludzkich, których nie da się zmierzyć żadną miarą [2,4]. Pomimo stosowania różnorodnych metod, mających na celu minimalizowanie możliwości kolizji statków powietrznych z ptakami, okazuje się, że oferowane sposoby nie dają oczekiwanych rezultatów $[1,3,4]$. Dlatego rozważany problem w dalszym ciągu jest otwarty i wymaga kontynuacji badań.

Kolizje z ptakami towarzyszą lotnictwu od początków jego istnienia. W początkowym okresie, gdy intensywność lotów była niewielka, a samoloty osiągały niewielkie prędkości, kolizje $\mathrm{z}$ ptakami nie stwarzały istotnego zagrożenia. Wraz z rozwojem lotnictwa wzrosła prędkość samolotów, co wiązało się z rosnącą liczbą wypadków lotniczych spowodowanych kolizjami z ptakami. Szczególnie wprowadzenie samolotów o napędzie odrzutowym wpłynęło na pogorszenie wskaźników bezpieczeństwa, gdyż ptaki są szczególnie groźne dla tego rodzaju silników [10]. Dodatkowym czynnikiem zwiększającym możliwość zderzenia samolotu z ptakami jest coraz mniejsza hałaśliwość silników lotniczych, ponieważ ptaki mają mniejszą możliwość zauważenia zagrożenia i uniknięcia kolizji.

Od roku 1960, wskutek zderzenia z ptakami, około 400 samolotów uległo katastrofom, w których zginęło 370 osób [4]. Najbardziej wrażliwe na uszkodzenia, wywołane przez ptaki, są samoloty wojskowe jednosilnikowe poruszające się $\mathrm{z}$ dużymi prędkościami zarówno $\mathrm{w}$ fazie startu, jak i podczas lądowania, gdzie prawdopodobieństwo zderzenia z ptakiem jest bardzo wysokie.

Jak wynika ze statystyk, problematyka zderzeń statków powietrznych z ptakami dotyczy również lotnictwa wojskowego [8]. Dlatego w niniejszym opracowaniu podjęto próbę dokonania analizy statystyki zderzeń zaistniałych w lotnictwie Sił Zbrojnych Rzeczypospolitej.

\section{Charakterystyka wybranych zderzeń wojskowych statków powietrznych z ptakami}

Dla podkreślenia wagi problemu zderzeń wojskowych statków powietrznych z ptakami wydaje się zasadne scharakteryzować wybrane przykłady zaistniałych zdarzeń.

W Polsce miały miejsce dwie katastrofy lotnicze, których główną przyczyną były zderzenia z ptakami. W dniu 3.08.1965 r. uczeń - pilot na samolocie TS-11 „Iskra” po starcie, na wysokości około $100 \mathrm{~m}$, wpadł w stado gołębi liczące kilkadziesiąt sztuk. Spowodowało to zgaśnięcie silnika. W czasie przymusowego lądowania 
samolot zahaczył lewym skrzydłem i statecznikiem pionowym o przewody dwóch linii energetycznych. W wyniku tego zderzenia nastąpiło urwanie części prawego skrzydła w odległości 1,5 m od końcówki, co spowodowało obrót samolotu w prawo wokół osi podłużnej i zderzenie z ziemią. Pilot poniósł śmierć na miejscu, a samolot uległ całkowitemu zniszczeniu $[3,4]$.

Innym wypadkiem była katastrofa śmigłowca Mi-14 Marynarki Wojennej. W dniu 15.06.1983 r. w czasie lotu na małej wysokości śmigłowiec zderzył się ze stadem gołębi i nastąpiło zgaśnięcie silników. Brak odpowiedniej wysokości uniemożliwiło załodze przeprowadzenie lądowania autorotacyjnego. Trzech członków załogi zginęło w czasie zderzenia śmigłowca z ziemią [4].

W dniu 9.04.1972 r. w czasie lotu rozpoznawczego na samolocie Lim-1A, na wysokości $400 \mathrm{~m}$ nastąpiło zderzenie z jastrzębiem. Przednia część osłony kabiny została zniszczona, a pilot doznał poważnych obrażeń głowy. Po szczęśliwym lądowaniu i zakołowaniu na stoisko pilot, na skutek obrażeń stracił przytomność. W wyniku doznanych obrażeń pilot stracił oko.

Dnia 20.10.1999 r. w czasie wizyty polskich pilotów wojskowych we Francji, w czasie lotu powrotnego do bazy lotniczej, na wysokości $600 \mathrm{~m}$ i prędkości około $800 \mathrm{~km} / \mathrm{h}$ nastąpiło zderzenie samolotu Su-22 ze stadem gęsi. Na skutek zderzenia nastąpiło uszkodzenie płatowca i silnika samolotu. Koszt remontu wyniósł 743505 złotych.
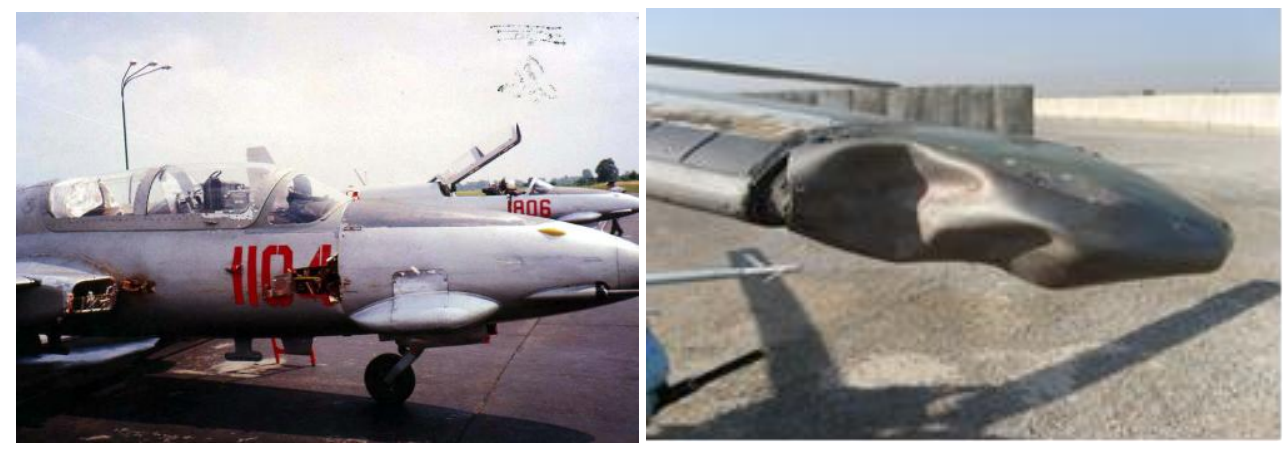

Fot. 1 Uszkodzony kadtub samolotu TS-11 oraz topata śmigłowca Mi-24 [4]

Dnia 14 lipca 1999 r. w czasie przelotu na wysokości 100 m nad lotniskiem Dęblin nastąpiło zderzenie z bocianem samolotu TS-11 „Iskra”. Uszkodzeniu uległa prawa część kadłuba i silnik. Na skutek zderzenia nastąpiło również częściowe zablokowanie steru kierunku. Koszty naprawy uszkodzeń wyniosły około 360000 złotych.

$\mathrm{Na}$ uwagę zasługuje zdarzenie z 17.06.2009 roku. Po starcie, na wysokości ok. 50-70 m załoga usłyszała głuche uderzenie z prawej strony samolotu (zderzenie z ptakiem). Po sprawdzeniu parametrów pracy silnika załoga wykonała lądowanie bez następstw. Jak widać na zdjęciu nr 2 samolot zderzył się z mewą, część ptaka 
Flight safety in the aspect of bird strikes in Polish Air Force.

Bezpieczeństwo lotów $w$ aspekcie kolizji statków powietrznych z ptakami...

dostała się do silnika. Przed dopuszczeniem samolotu do dalszej eksploatacji wykonano odpowiednie zalecenia sprawdzające silnik w zakładzie remontowym, koszt remontu wyniósł około 400000 zł. Należy podkreślić, że przypadek miał miejsce w czasie stosowania odstraszania ptaków przez sokoła. Okazuje się, że sokół nie odstrasza mew $[4,7]$.
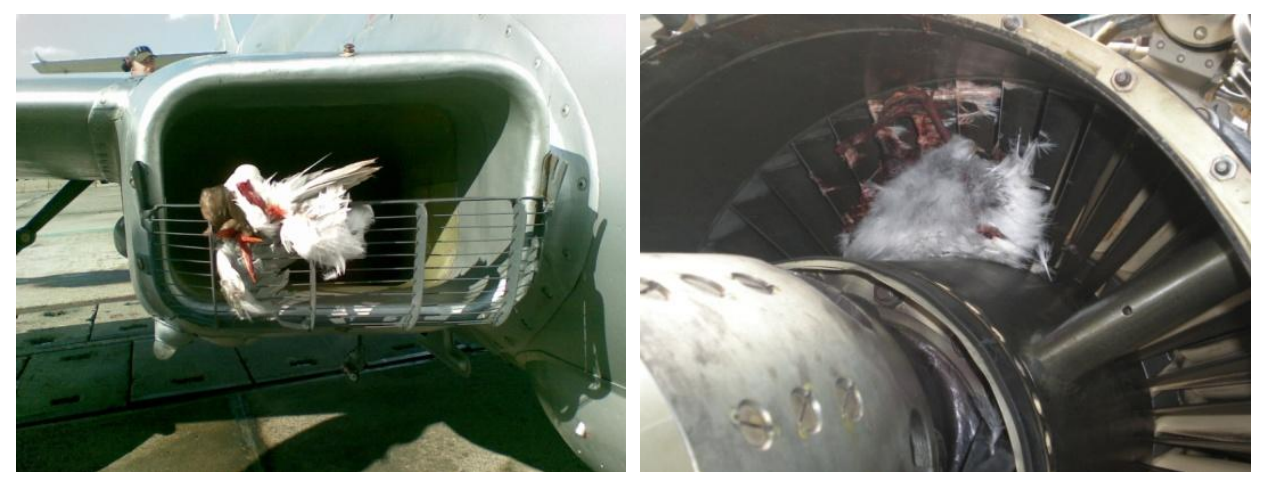

Fot. 2 Zderzenie samolotu TS-11 z mewa [4]

Również na śmigłowcach odnotowano szereg kolizji z udziałem ptaków. Jedno z nich miało miejsce $w$ dniu 19.09.2007 r. Na śmigłowcu Mi-24, po locie celem wykonania zadania bojowego - osłona patrolu, w czasie obsługi technicznej personel techniczny wykrył usterkę polegającą na uszkodzeniu opływu końcowego łopaty wirnika nośnego (fot.1). Załoga $\mathrm{w}$ trakcie lotu nie odczuła symptomów uszkodzenia. Prawdopodobną przyczyną uszkodzenia było uderzenie ptaka w końcówkę łopaty wirnika nośnego, o czym świadczą liczne ślady krwi i piór na łopacie.

Jak wynika z przedstawionej charakterystyki zaistniałych kolizji miały one miejsce na różnych typach statków powietrznych i w różnych okolicznościach.

Wyraźnego podkreślenia wymaga fakt, że prawie każdy przypadek kolizji generuje straty finansowe związane $\mathrm{z}$ remontem statku powietrznego, bądź wynikłe z konieczności wykonania sprawdzenia jego stanu technicznego. Koszty to także przerwy w wykonywaniu lotów przez dany egzemplarz przekazany do remontu lub sprawdzenia.

Jak wynika $\mathrm{z}$ analizowanych danych, $\mathrm{w}$ lotnictwie wojskowym, 6\% statków powietrznych biorąca udział $\mathrm{w}$ zderzeniach $\mathrm{z}$ ptakami wymagała remontu. Pomimo faktu, że tylko niewielka liczba statków powietrznych wymaga remontu, należy zaznaczyć, że remont statku powietrznego jest bardzo kosztowny. Przykładowo remont samolotu TS-11 „Iskra” po zderzeniu z bocianem w Dęblinie dnia 14 lipca 1999 roku wyniósł około 360000 złotych, a w wyniku zderzenia samolotu TS-11 z mewą, remont silnika oszacowano na $400000 \mathrm{zt}$.

Ogólnie szacuje się, że roczne koszty ponoszone przez lotnictwo wojskowe w Polsce, spowodowane kolizjami z ptakami i innymi zwierzętami wynoszą około 
500000 Euro i są porównywalne z tego rodzaju kosztami w Siłach Powietrznych Holandii [3]. Natomiast w Siłach Powietrznych Wielkiej Brytanii koszty te kształtują się na poziomie $18 \mathrm{mln}$ Euro, a w USA wynoszą aż $26 \mathrm{mln}$ Euro.

Rysunek 1 zawiera istotne dane dotyczące uszkodzeń różnych części statku powietrznego z punktu widzenia ponoszonych strat oraz zagrożeń bezpieczeństwa lotów.

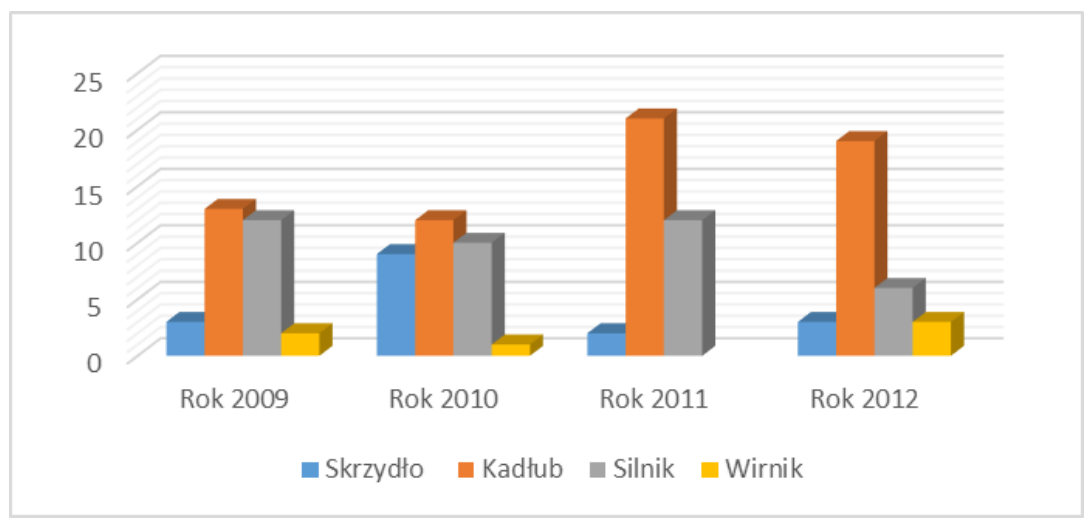

Rys. 1 Podziat kolizji ze względu na rodzaj uszkodzeń statków powietrznych w latach 2009 - 2012 [8]

Podkreślania wymaga fakt, że na skutek kolizji samolotu z ptakami najczęściej ulega uszkodzeniom silnik, co ma bezpośredni wpływ na bezpieczeństwo lotu. W drugiej kolejności na uszkodzenia narażony jest kadłub samolotu.

\section{Analiza zdarzeń lotniczych spowodowanych kolizjami statków powietrznych z ptakami i innymi zwierzętami}

Jak wynika $\mathrm{z}$ analizy literatury przedmiotu badań wpływ na zaistniałe kolizje statków z ptakami miało wiele czynników. Ze względu na ograniczenia związane $\mathrm{z}$ rozmiarem niniejszego opracowania analizie poddano tylko wybrane uwarunkowania.

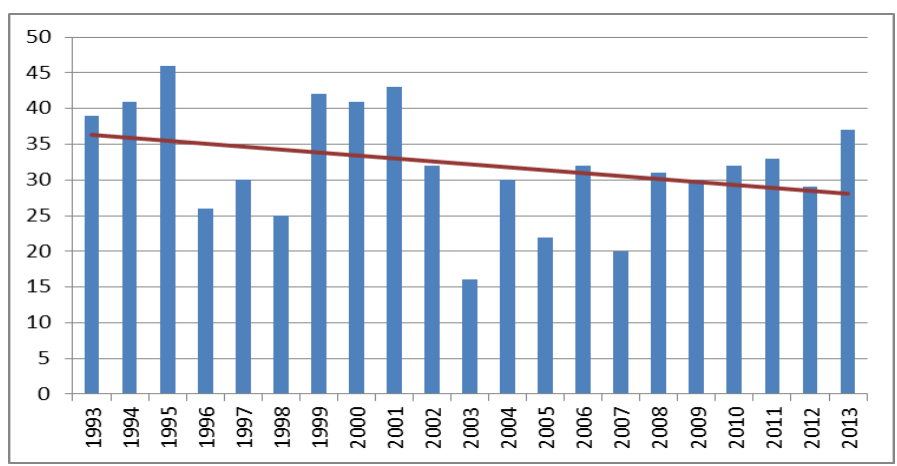

Rys. 2 Rozktad kolizji zaistniatych w lotnictwie SZ RP w latach 1993-2013 [3] 
Flight safety in the aspect of bird strikes in Polish Air Force.

Bezpieczeństwo lotów $w$ aspekcie kolizji statków powietrznych z ptakami...

Jak wynika z danych prezentowanych na rysunku 2, w ciągu ostatnich dwudziestu lat liczba kolizji kształtuje się na paziomie okoł 32 rocznie z nieznaczną tendencją spadkową.

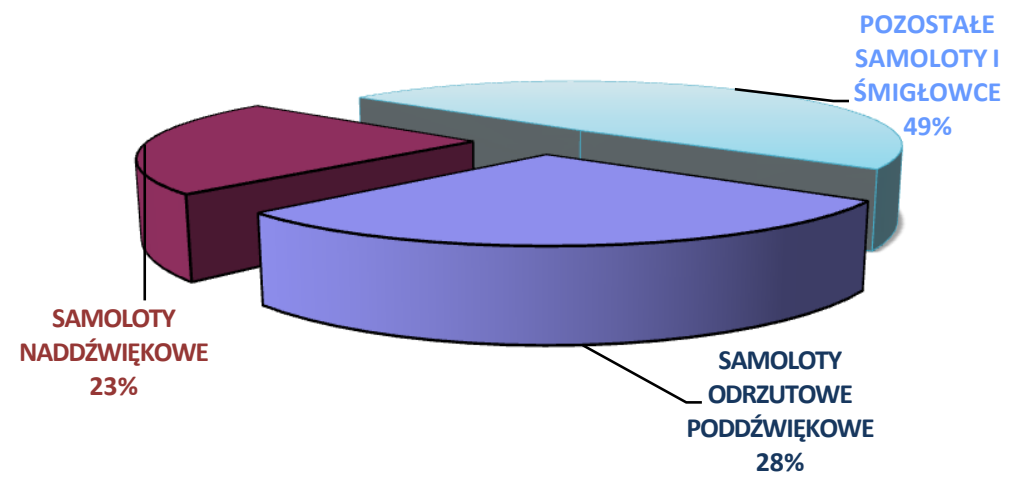

Rys. 3 Podział na rodzaje statków powietrznych bioracych udziat $w$ zdarzeniach w latach 1992-2008 [8]

Analizując dane prezentowane na rysunku 3 okazuje się, że w polskim lotnictwie wojskowym najczęściej do zderzenia $\mathrm{z}$ ptakami dochodzi na samolotach odrzutowych naddźwiękowych (49\%). Najprawdopodobniej spowodowane jest to dużą prędkością samolotów, co skutkuje krótkim czasem reakcji pilota na wykonanie manewru antykolizyjnego, podobnie ptaki nie mają czasu zareagować na zbliżające się nieuchronnie zagrożenie. $Z$ dużej prędkości lotu wynika też duża energia zderzenia $\mathrm{z}$ ptakiem oraz charakter i rozmiary uszkodzeń samolotu, zagrażające często bezpieczeństwu lotu.

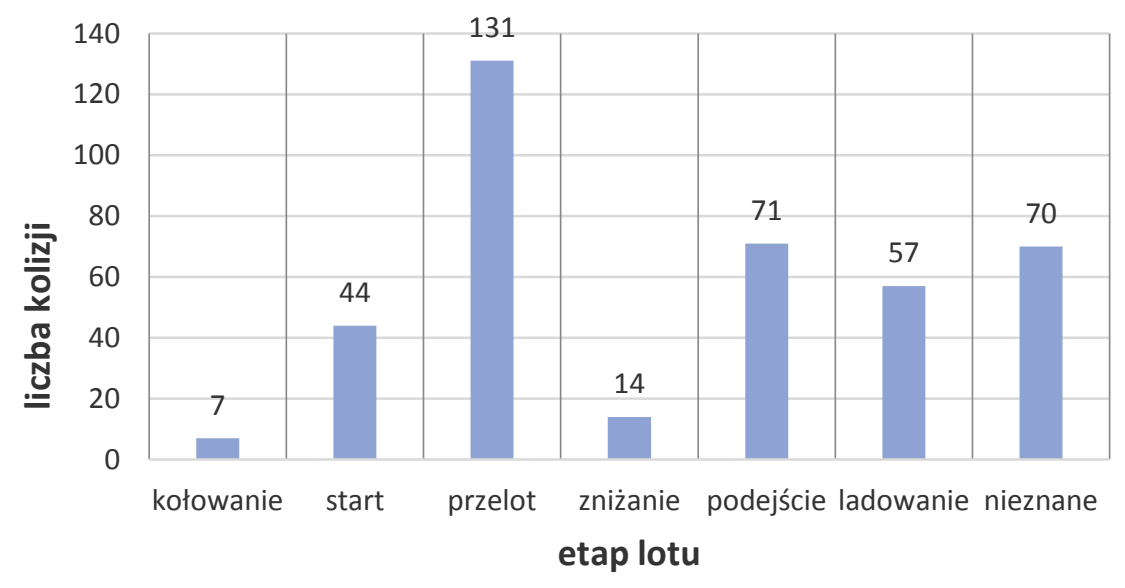

Rys. 4 Rozktad zderzeń statków powietrznych z ptakami w zależności od etapu lotu w latach $2000-2012$ 
Najwięcej zderzeń statków powietrznych z ptakami miało miejsce podczas operacji poza lotniskowych $(37 \%)$, natomiast najmniej podczas kołowania. Jednak sumując operacje związane ze startem, zniżaniem, podejściem do lądowania oraz lądowaniem należy stwierdzić, że jednak większość kolizji ma miejsce w operacjach nadlotniskowych (47\%).

Należy zaznaczyć, że pomimo stosowania różnych metod mających na celu zmniejszenie populacji ptaków na lotnisku i w jego okolicy, a tym samym zmniejszenie ryzyka kolizji w dalszym ciągu większość przypadków ma miejsce w operacjach lotniskowych. Dlatego trzeba zintensyfikować wszelkie działania profilaktyczne, aby zmniejszyć ryzyko kolizji statków powietrznych z ptakami podczas operacji lotniskowych do akceptowalnego.

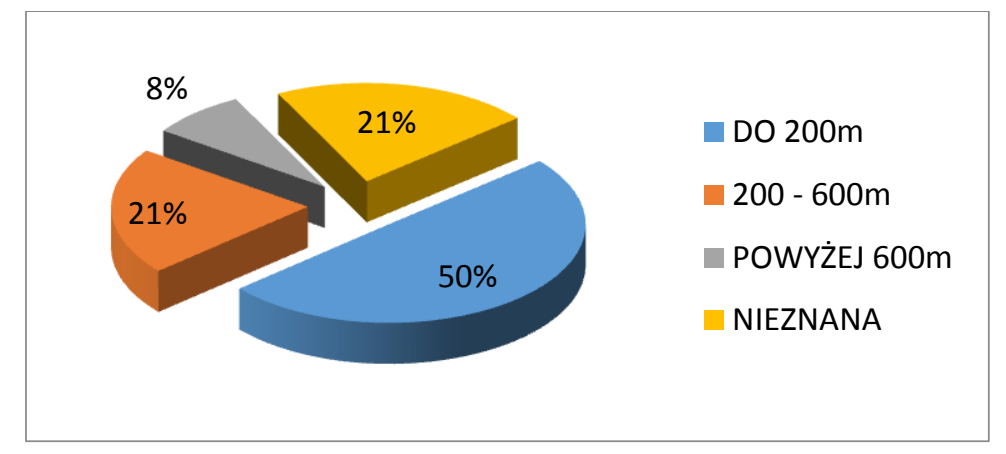

Rys. 5 Wykaz zderzeń statków powietrznych z ptakami w zależności od wysokości lotu w latach 2000-2008

Z punktu widzenia uwzględnienia ryzyka kolizji w procedurach operacji powietrznych, istotnym rozkładem jest rozkład kolizji pod względem wysokości. Okazuje się, że połowa zderzeń miała miejsce na wysokości do $200 \mathrm{~m}$. Jest to spowodowane największą obecnością i aktywnością ptaków na wysokościach w pobliżu ziemi wynikająca $\mathrm{z}$ behawioru ptaków. Tym samym wraz ze wzrostem wysokości populacja ptaków maleje i prawdopodobieństwo kolizji jest mniejsze. Jednak należy zaznaczyć, że na wysokościach powyżej $200 \mathrm{~m}$ latają ptaki o znacznej masie (bociany, żurawie, łabędzie, gęsi), a więc skutki kolizji mogą być bardziej dotkliwe [5].

\section{Rozkład zderzeń statków powietrznych $z$ ptakami w zależności od pory roku w aspekcie sytuacji ornitologicznej}

Jak wynika $\mathrm{z}$ przeprowadzonych analiz jednym z czynników zwiększających możliwość kolizji statków powietrznych z ptakami są uwarunkowania związane ze zwiększoną aktywnością ptaków w niektórych okresach roku. Dla potwierdzenia powyższej tezy poniżej przedstawiono statystyki zderzeń w poszczególnych miesiącach roku zarówno zaistniałych $\mathrm{w}$ lotnictwie cywilnym oraz w lotnictwie wojskowym w Polsce. 
Flight safety in the aspect of bird strikes in Polish Air Force.

Bezpieczeństwo lotów $w$ aspekcie kolizji statków powietrznych z ptakami...

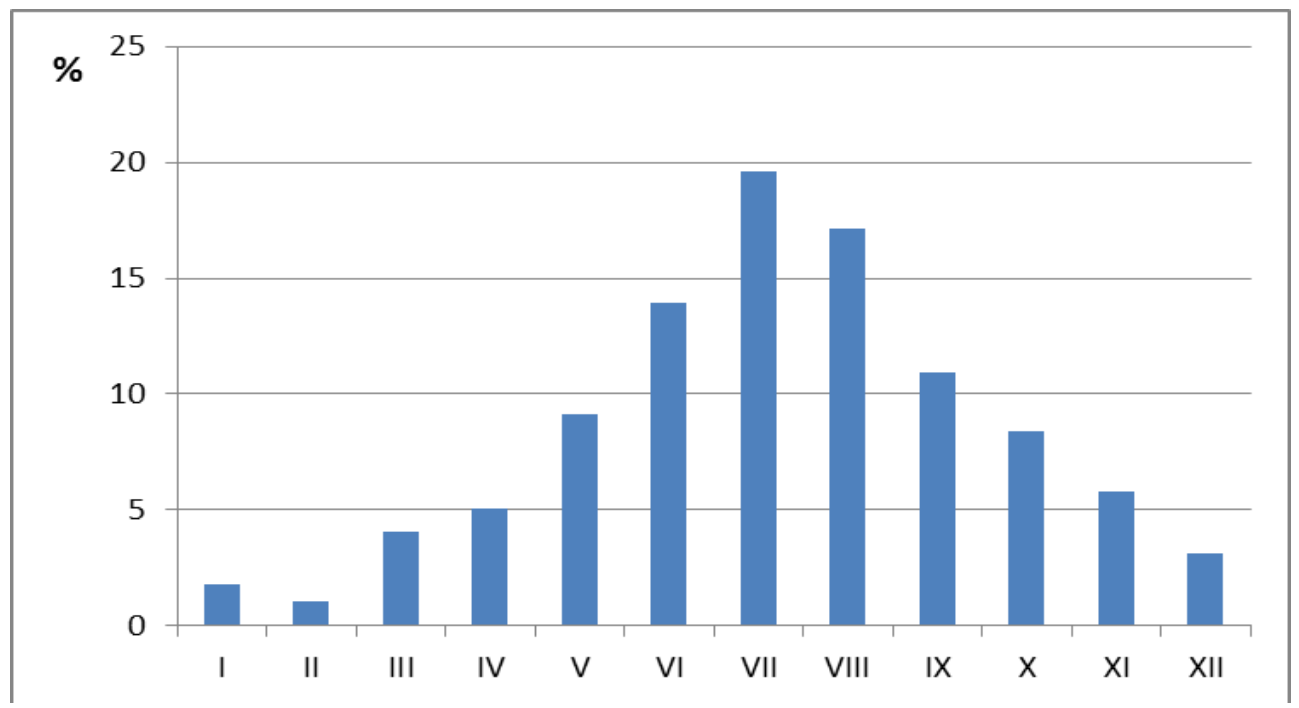

Rys. 6 Liczba zderzeń statków powietrznych zaistniatych w lotnictwie cywilnym w poszczególnych miesiacach w latach 2006-2013 [6]

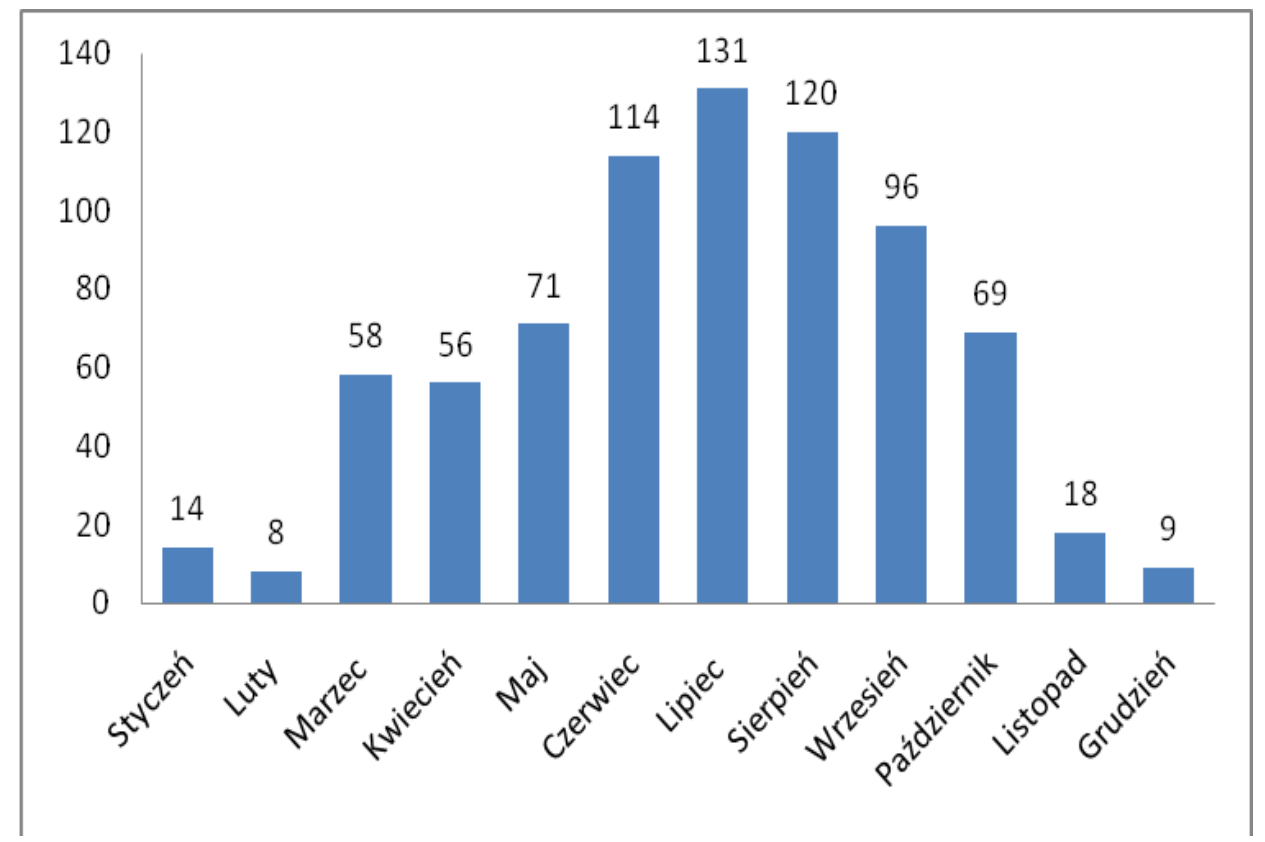

Rys. 7 Liczba zderzeń statków powietrznych zaistniałych w lotnictwie wojskowym w poszczególnych miesiacach w latach 1982-2000 [10] 


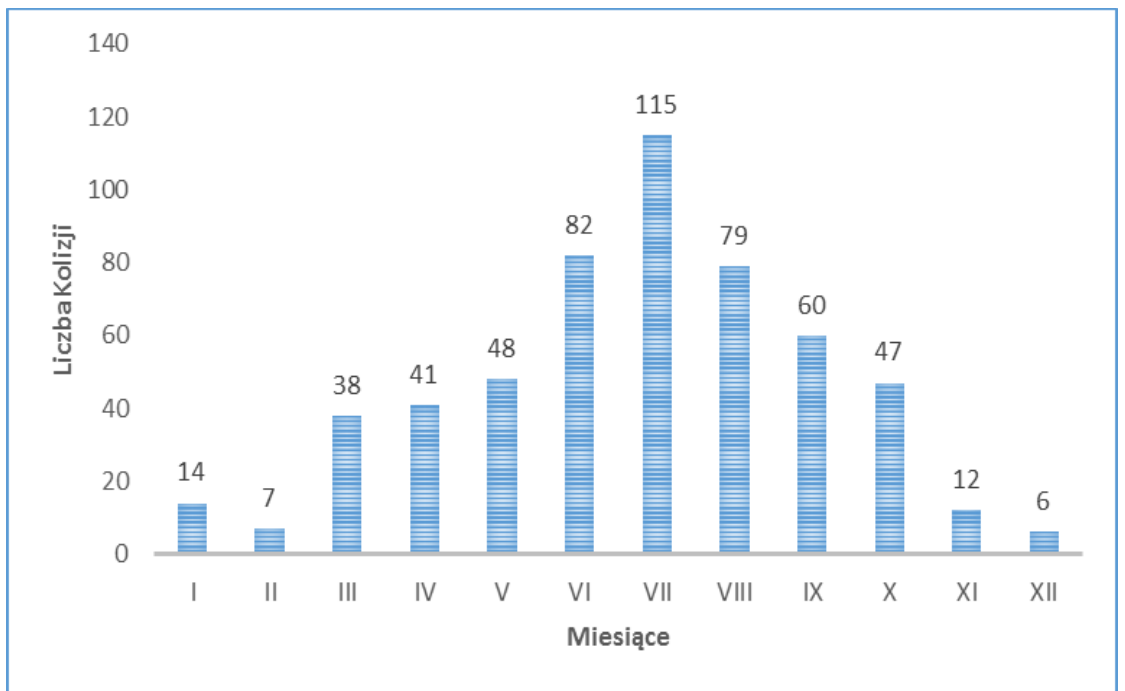

Rys. 8 Liczba zderzeń statków powietrznych zaistniałych w lotnictwie wojskowym w poszczególnych miesiacach w latach 2000-2008

Jak wynika z prezentowanych danych na rysunkach $6,7,8$ zarówno w lotnictwie cywilnym jak i w lotnictwie wojskowym najwięcej kolizji miało miejsce w okresie letnim, a w szczególności w lipcu. Fakt ten jest ściśle związany zarazem z wzmożoną aktywnością ptaków oraz zwiększoną intensywnością lotów szczególnie w lotnictwie wojskowym. Również w okresie wiosennym należy zwrócić uwagę na zwiększoną aktywność ptaków związaną z okresem rozrodczym.

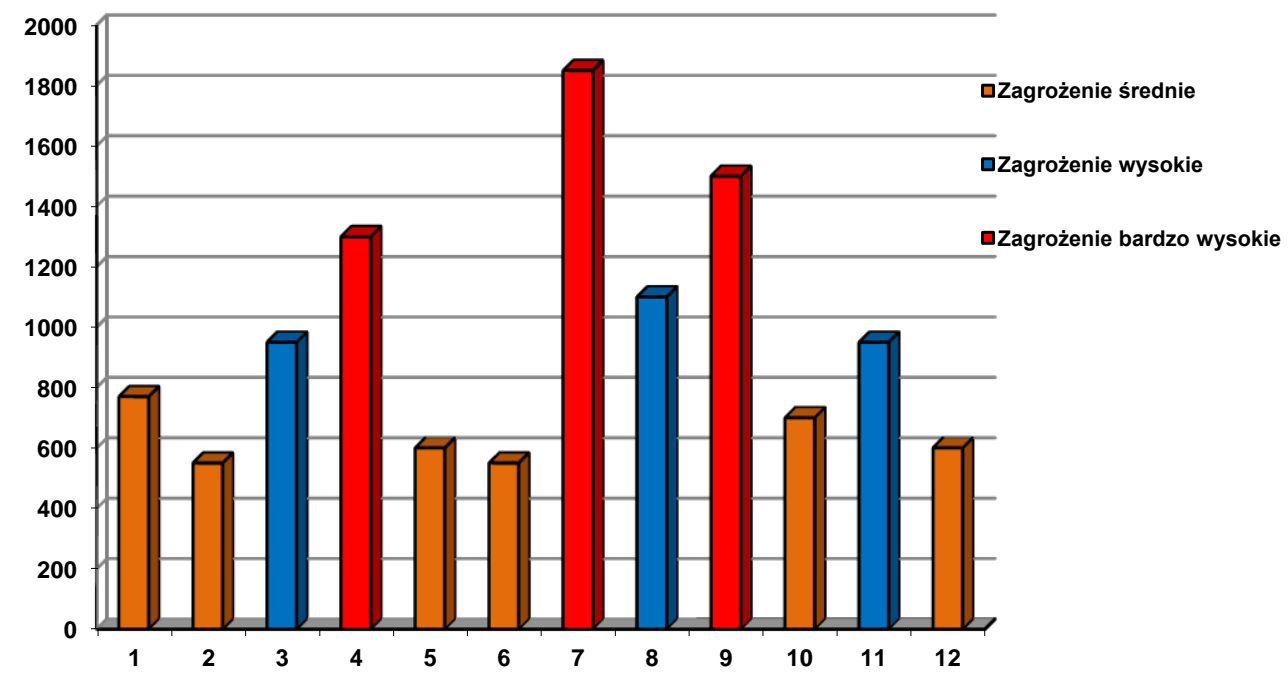

Rys. 9 Rozkład zagrożeń w poszczególnych miesiacach wg liczebności ptaków na lotnisku w Dęblinie [10] 
Flight safety in the aspect of bird strikes in Polish Air Force.

Bezpieczeństwo lotów $w$ aspekcie kolizji statków powietrznych z ptakami...

Rozpatrując dane prezentowane na rysunku 9, sytuacja wygląda podobnie jak na poprzednich rysunkach, okres bardzo wysokiego zagrożenia przypada na miesiące letnie, a więc okres największej intensywności lotów. Dane te silnie korelują z wykresami zawierającymi rozkład liczby zaistniałych zderzeń zarówno w lotnictwie wojskowym jak i cywilnym. Co oznacza, że biorąc pod uwagę uwarunkowania awifauny w Polsce, okres letni i wczesnowiosenny stwarza duże prawdopodobieństwo zaistnienia kolizji statku powietrznego z ptakami. Ponadto z prezentowanych danych zawierających statystyki kolizji oraz rozkład obecności i aktywności ptaków na lotnisku, można wysnuć wniosek, że podstawą określenia zagrożeń dla danego lotniska może być sytuacja ornitologiczna, a niekoniecznie rozkład zaistniałych kolizji. Problem ten dotyczy zwłaszcza nowych lotnisk, na których zdarzeń tego typu nie było, a sytuacja środowiskowa, w formie decyzji, jest jednym z warunków dopuszczenia lotniska do eksploatacji.

Reasumując, jak wynika $\mathrm{z}$ przedstawionych danych, największe zagrożenia występują pomiędzy lipcem a październikiem, chociaż pierwszy okres zwiększonego zagrożenia rozpoczyna się już w marcu. Pora doby największych zagrożeń zderzeń z ptakami to dzień w godzinach od 10 do 16 .

Największe zagrożenie stwarzają sezonowe nierozpoznane migracje ptaków. Prawdopodobieństwo kolizji samolotów z ptakami wzrasta podczas wiosennych i jesiennych przelotów (kwiecień, maj oraz od połowy lipca do października).

W zależności od gatunku ptaków i warunków meteorologicznych, zbiorowe migracje odbywają się zarówno w dzień, jak i w nocy, najczęściej na wysokościach do $500 \mathrm{~m}$. Niektóre gatunki, na przykład żurawie, gęsi, kaczki, bociany i inne latają na wysokościach do $1000 \mathrm{~m}$ lub wyżej; nie trzymają się tradycyjnych tras przelotów i z tego względu są one bardziej niebezpieczne.

Specyficzną formą przelotów i zarazem jedną z najbardziej kolizyjnych są pierwsze wyloty młodych ptaków po okresie lęgowym. Stąd bardzo ważne jest, aby orientować się co do gatunków ptaków, jakie występują w rejonie lotniska oraz terminów zakończenia ich okresów lęgowych.

\section{Zakończenie}

Ja wynika z przeprowadzonych analiz kolizje statków powietrznych z ptakami, podobnie jak $\mathrm{w}$ innych krajach, stanowią poważny problem $\mathrm{w}$ lotnictwie wojskowym w Polsce. Pomimo stosowania różnorodnych metod ograniczających populacje ptaków na lotnisku i jego okolicy liczba tego typu zdarzeń utrzymuje się na podobnym poziomie od 1991 roku i wynosi średnio około 32 przypadki w roku. 
Liczba kolizji z ptakami jest zróżnicowana na poszczególnych lotniskach i zależy między innymi od:

- położenia geograficznego lotniska;

- środowiska naturalnego na lotnisku i wokół niego;

- sposobów i metod zapobiegania zderzeniom statków powietrznych z ptakami;

- intensywności lotów.

Reasumując, nie bez znaczenia dla liczby zderzeń statków powietrznych z ptakami jest wysokość lotu statku powietrznego. Analiza zderzeń, uwzględniająca jako kryterium wysokość lotu samolotu, pozwala jednoznacznie stwierdzić, że najczęściej dochodzi do kolizji w przedziale wysokości 200-300 m. Wraz ze wzrostem wysokości zmniejsza się liczba ptaków, a tym samym maleje prawdopodobieństwo zderzenia z nimi. Liczba zderzeń z ptakami zależy także od etapu lotu. Ze statystyk wynika, że najczęściej do kolizji z ptakami dochodzi w czasie operacji powietrznych związanych ze startem, odlotem z lotniska i podejściem do lądowania, a najrzadziej podczas kołowania i rozbiegu. Przyjmuje się, że kołowanie i rozbieg trwają stosunkowo krótko i charakteryzują się dużym nasileniem hałasu, ponadto na lotniskach stosuje się różne sposoby odstraszania ptaków.

Ponadto, podkreślenia wymaga fakt, że pomimo zmniejszenia nalotu w ostatnich kliku latach, w lotnictwie wojskowym, liczba kolizji pozostaje na podobnym poziomie. Biorąc powyższe pod uwagę należy przyspieszyć wprowadzenie zarządzania bezpieczeństwem $\mathrm{w}$ bazach lotniczych $\mathrm{w}$ aspekcie ryzyka kolizji statków powietrznych z ptakami i innym zwierzętami.

\section{Literatura}

[1] Adamski M., Masłowski A., On civil air task and e-training problems of UAV applications, Zeszyty Naukowe AMW 185A/2011 str 7-18

[2] Cleary E.C., Dolbeer R.A, Wright S.E. (2006): Wildlife strikes to civil aircraft in the United States 1990-2005. U.S. Dept. Of Agriculture. Federal Aviation Administration. National Wildlife Strike Database Serial Report 12.

[3] Ćwiklak J., Skakuj M., Ziółkowski J., Wildlife Strikes in Polish Air Force, ICAO, World Birdstrike Association \& CARSAMPAF Bird/Wildlife Strike Prevention Conference, Santa Fe, Mexico City, Mexico, 20-24 October 2014

[4] Ćwiklak J., Zagrożenia i metody ochrony statków powietrznych przed zderzeniami $\mathrm{z}$ ptakami $\mathrm{W}$ aspekcie sytuacji ornitologicznej lotniska wojskowego w Dęblinie, WSOSP, Dęblin 2010

[5] Dzik T. and Kiernicki A.: Ptaki - użytkownicy przestrzeni powietrznej (Birds as Users of the Air Space). The Air Force Review No 8; 21-36. 2005. 
Flight safety in the aspect of bird strikes in Polish Air Force.

Bezpieczeństwo lotów $w$ aspekcie kolizji statków powietrznych z ptakami...

[6] Grabowska B., Wspólne niebo - wspólna sprawa. Konflikt człowieka z przyrodą - bezpieczeństwo lotów w aspekcie ryzyka kolizji statków powietrznych z ptakami. I Międzynarodowa Konferencja Naukowa. Dęblin. 2009.

[7] Kitowski I., Grzywaczewski G., Ćwiklak J., Grzegorzewski M., Krop S. Falconer activities as a bird dispersal tool at Deblin Airfield (E Poland) Transportation Research Part D 16 (2011) 82-86

[8] Kwiek O., Analiza bezpieczeństwa lotów w aspekcie zderzeń statków powietrznych z ptakami w lotnictwie SZ RP, praca inż. WSOSP, Dęblin 2013

[9] Manual on the ICAO Bird Strike information System (IBIS) Doc. 9332.

[10] Szczepanik R., Szymczak J.: Colisions of military aircraft with birds in the airfield airspace in Poland: Air Force Institute of Technology. International Bird Strike Committee 26th Meeting Proceedings I Warsaw. Poland. Warszawa 2003.

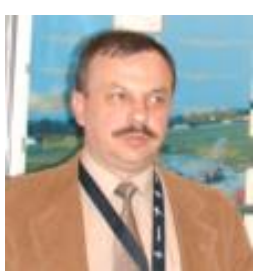

Dr pil. Janusz Ćwiklak zwiazany jest z lotnictwem od 1976 roku. Jest absolwentem kierunku „pilot samolotu odrzutowego" Wyższej Oficerskiej Szkoty Lotniczej. Ukończyt studia magisterskie na Politechnice Lubelskiej. W 2002 roku na Uniwersytecie Warmińsko-Mazurskim obronit rozprawe doktorska uzyskując stopień doktora nauk technicznych $w$ zakresie geodezji i kartografii. Zajmuje się działalnościa naukowa, związana $z$ zastosowaniem systemów satelitarnych $w$ lotnictwie. Prowadzi badania poświęcone zagadnieniom bezpieczeństwa lotów, ze szczególnym uwzględnieniem problematyki zapobiegania kolizjom statków powietrznych z ptakami. Uczestnik wielu konferencji międzynarodowych $i$ krajowych. Od 2008 roku pracuje w WSOSP jako cywilny nauczyciel akademicki, petniac funkcje prodziekana Wydzialu Lotnictwa.

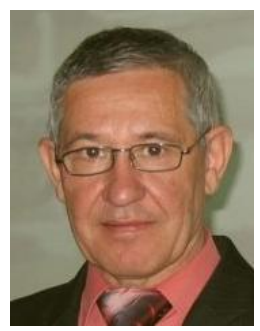

Dr inż. pil. Henryk Jafernik - docent Politechniki Ślaskiej, adiunkt $w$ Katedrze Nawigacji Lotniczej Wyższej Szkoly Oficerskiej Sił Powietrznych. Współautor trzech podręczników oraz ponad 70 artykutów $i$ prac naukowych opublikowanych $w$ kraju $i$ za granica. Uczestnik projektów badawczych z dziedziny nawigacji satelitarnej. 